University for Business and Technology in Kosovo

UBT Knowledge Center

UBT International Conference

2012 UBT International Conference

Nov 2nd, 9:00 AM - Nov 3rd, 5:00 PM

\title{
Current Developments, Issues and the Future of Microfinance in
}

\section{Albania}

Oltiana Muharremi

University of Vlora, olta.muharremi@gmail.com

Erald Pelari

University of Vlora, erald.pelari@univlora.edu.al

Follow this and additional works at: https://knowledgecenter.ubt-uni.net/conference

Part of the Business Commons

\section{Recommended Citation}

Muharremi, Oltiana and Pelari, Erald, "Current Developments, Issues and the Future of Microfinance in Albania" (2012). UBT International Conference. 58.

https://knowledgecenter.ubt-uni.net/conference/2012/all-events/58

This Event is brought to you for free and open access by the Publication and Journals at UBT Knowledge Center. It has been accepted for inclusion in UBT International Conference by an authorized administrator of UBT Knowledge Center. For more information, please contact knowledge.center@ubt-uni.net. 


\title{
Current Developments, Issues and the Future of Microfinance in Albania
}

\author{
Oltiana Muharremi, PhD Student Finance \\ olta.muharremi@gmail.com; oltiana.muharremi@univlora.edu.al \\ Erald Pelari, Lecturer in Finance \\ erald.pelari@univlora.edu.al \\ Department of Finance \\ University of Vlora \\ "Ismail Qemali"
}

\begin{abstract}
One of the trends of global development today is microcredit. It is an instrument affecting employment, social, cultural and economic issues, and also as a component of natures cultures destined to have a great importance in the economies of different countries in the future. The careful determination of supply and demand for microcredit and the increasing role of small businesses to be economically productive and perform services in favor of society, undoubtedly requires a cautious policy in the development of microfinance institutions.

Microfinance developed in Albania in the 90s and since then has been a key element in its development and economic environment. It is now a recognized part of the financial markets thanks to the support of donors and the serious involvement of the government.

Overall economic development of the country, the creation of new jobs, increase the standard of living, increase social stability, political and economic development of Albania and the region in general, interregional cooperation and integration of Albania into European structures cannot be understood, if we do not develop a human and natural reserves, but this development cannot be done without strong financial support.

So what small business financing systems will be developed in the future, what will be the position and its role in the economy, what policies will be pursued funding to balance demand and supply in this market? These and others are the subject of this paper since it is difficult to determine a solid line because microcredit is a growing and variable phenomenon.

Without understanding the effects and necessity of economic development of the microfinance market, one cannot understand the essential role of microfinance in the growth and positioning of small business.
\end{abstract}

Keywords: microcredit, SMEs, financial sector development, donors contribution. 